\title{
ASSESSMENT OF USAGE OF TREATED FAECAL SLUDGE FOR AGRICULTURE
}

\author{
B.T.Shivendra ${ }^{1}$, Tejaswini $\mathbf{M}^{2}$, Poornima Kamatagi ${ }^{3}$, Tejaswini P $\mathbf{S}^{4}$ \\ ${ }^{1}$ Associate Professor, Civil Department, DSCE, Bangalore, India \\ ${ }^{2,3,4}$ Assistant Professor, Civil Department, DSCE, Bangalore, India
}

\begin{abstract}
Developing countries are unable to manage the faecal sludge. The Faecal sludge is disposed in open low lying areas or it is used as manure in agricultural field with or without proper treatment. The fecal sludge is used in wet/dry form in the agricultural lands to grow the vegetables which come in contact with sewage water. This type growing of vegetables will be responsible for various diseases which resulting in water borne diseases, causing widespread morbidity and mortality. Usage of untreated faecal sludge causes contamination of soil and water bodies and human health. The killing of pathogens before application can reduce the negative impacts on environment and on human health. In present study co-composted of faecal sludge with solid organic waste is carried to recovery valuable nutrient from faecal sludge in Devanahalli suburban area. The feasibility of fecal sludge and/or market waste composting into fortifier in Devanahalli was studied. The study indicates that the fecal sludge can be utilized as manure without health effect for cultivation of crops.
\end{abstract}

Keywords: Fecal Sludge, Fertilizer, Onsite Sanitation, Co- Composting,

\section{INTRODUCTION}

As many of the developing countries are moving towards increased sanitation coverage, the issue of safe handling of sludge has gained more attention of researchers. In cities where most households practice on-site sanitation, the emptying septic of tanks or pits, and transport of sludge to a safe dumping site for treatment becomes an emerging need. The fecal sludge management (FSM) reduction helps in protecting public health and environment

In the town of Devanahalli where the underground sanitation system doesn't exist, the fecal sludge which is being generated is being dumped at various open fields. This practice poses a great threat to human health. Hence it is very much necessary to dispose this faecal sludge being generated in a scientific and sustainable way. This is being achieved by setting up the faecal sludge treatment plant. The final product of this treatment plant is planned to be reused as soil conditioner for the nearby agricultural fields.

The treated faecal sludge which is obtained from the drying bed of the faecal sludge treatment plant at Devanahalli consists of Pathogens (Helminthes Eggs) which is not desirable for the application of faecal sludge to the agricultural field. In order to eliminate this, co-composting of the faecal sludge with organic municipal solid waste is adopted. This treated faecal sludge is thereby planned to be given to the farmers in order to reuse this as manure. So, it is very much necessary to know if the nearby farmers are ready to use this treated sludge as manure. Hence this study is carried out to assess the usage of treated faecal sludge by the farmers for agriculture.

\subsection{Faecal Sludge Management In India}

End Quantity of faecal sludge produced in India is about 0.12 million tons/day from open defection and from onsite sanitation. The Government of India's goal is for all cities to have networked sewerage connections, which would send fecal sludge to a central location for treatment and disposal. Presently, 95\% of towns do not have this infrastructure. This means that septic tanks or pits have to be emptied and moved to a location that will process the fecal sludge. In higher apartment complexes and business centers, there are on-site Faecal Sludge Management solutions; however, it remains a challenge even here where space and options for dumping the treated waste are limited. There is little regulatory power to monitor whether fecal sludge is processed according to environmental and health standards. Most cities in India lack the capacity to regulate treatment and dumping of waste.

There is also a lack of approved sewage treatment plants (STPs) in the country to safely and effectively treat fecal sludge, if it is actually collected and able to be sent there.

Due to the lack of functioning STPs and adequate enforcement of regulations, untreated fecal sludge is disposed indiscriminately into water bodies, drains, landfills, and vacant lands. In Bhubaneswar, Orissa for example, untreated fecal sludge is often dumped directly into the sea. As with the on-site FSM options, city wide STPs often still have the problem of responsibly dealing with the treated sludge. The faecal sludge is directly reused in Agriculture and Aquaculture because of its nutrient values and Treated Faecal Sludge is reused as a soil additive. 


\section{STUDY AREA}

Devanahalli is peri urban area located at a latitutude and longitude $13^{\circ} 13^{\prime} 48^{\prime \prime} \mathrm{N}, 77^{\circ} 42^{\prime} 0^{\prime \prime} \mathrm{E}$ in Bangalore Rural district, Karnataka, India.. The Devanahalli is having population of 28,039 as per report released by Census India 2011. Devanahalli Town Municipal Council has total administration over 6,400 houses to which it supplies basic amenities like water and sewerage.

\subsection{Water Supply and Sewerage System}

At present the Devanahalli Town is having a population of 35000. Existing Bore wells are 55 and total no. of Bore wells working presently are 48 Average daily yield from these sources in one week is 617400 Gallon.

Devanahalli peri urban area is not having sewerage system and households are depend on soak pit and septic tanks for onsite sanitation.. About 5110 households are provided with individual sanitation facility i.e. septic tank and rest of the town residents use the existing public toilets or resort to open air defecation. In some cases the sewer out let is directly let into the drain. Most of the night soil is washed out through the existing drains causing nuisance and health hazard to the entire TMC area. Presently there is no facility to safely dispose the waste water. In order to treat the total volume of sewage generated in the year 2033, Sewage Treatment Plant of capacity 8.63 MLD is considered. It is suggested to construct additional 4 public conveniences or sanitary complexes at various places identified in different slum areas.

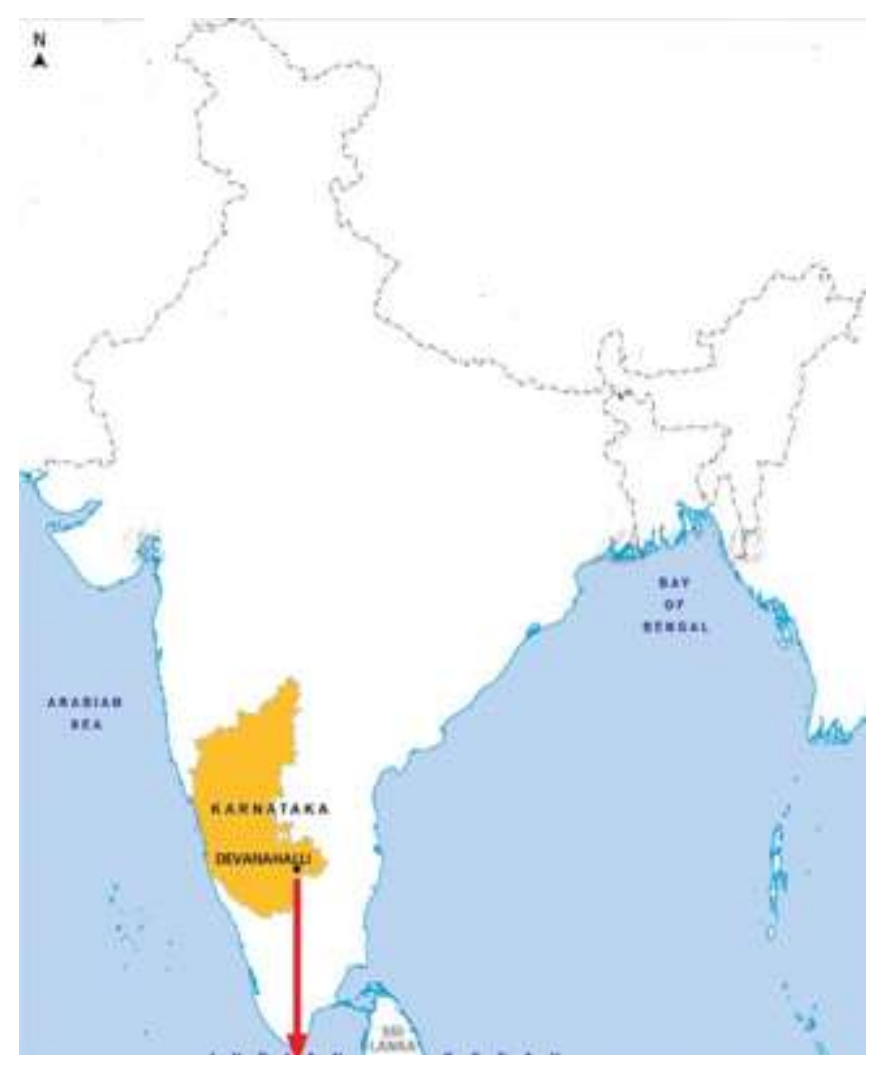

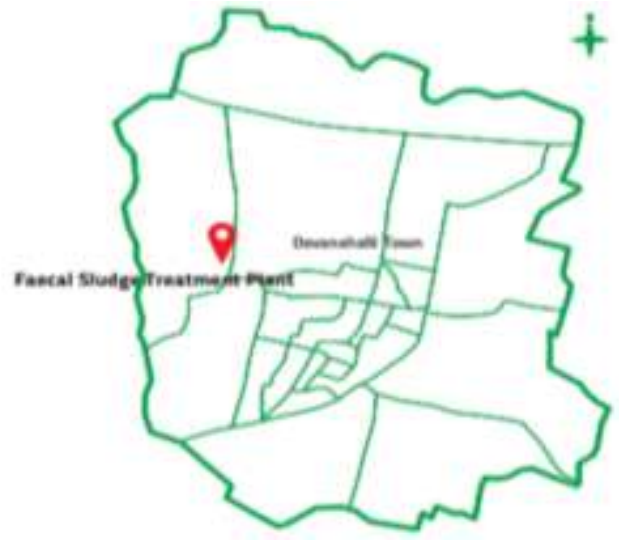

Fig 1: Map of the study area

3. FAECAL SLUDGE TREATMENT PLANT DETAILS IN DEVANAHALLI

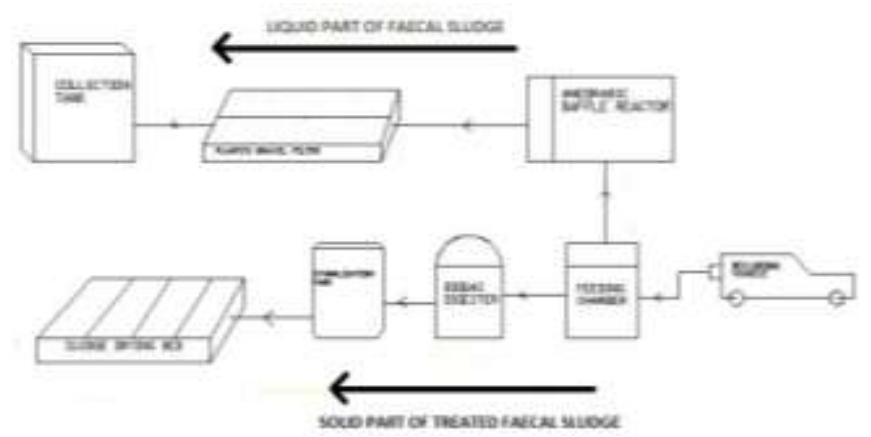

Fig 2: Flow chart of the treatment plant

\subsection{Desludging Vehicle}

Waste is been collected and transported with the help of the De-sludging vehicle also known as honey suckers

\subsection{Feeding Tank}

The feeding tank has screening chamber which is used to separate solid waste from Faecal Sludge. The feeding tank helps in separation of liquid and solid fraction of Faecal Sludge within $3-4 \mathrm{hrs}$. This feeding tank is almost trapezoidal at the top and tapering towards the bottom and this feeding tank has a graduated scale fixed to it. This graduated scale helps knowing the level of FS in liter's in the feeding tank.

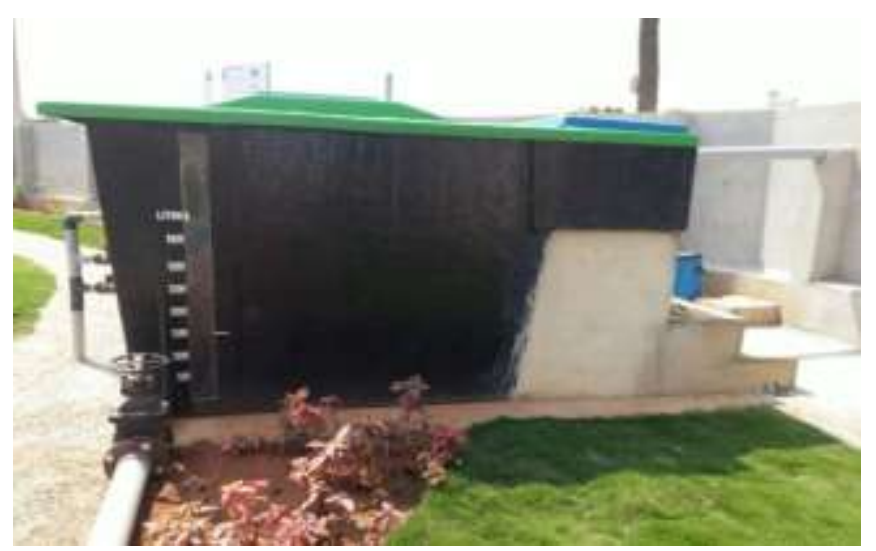

Fig 3: Feeding Tank 


\subsection{Bio Gas Digester}

The biogas digester is spherical in shape, as the name suggests it helps in digestion of the faecal sludge by anaerobic process. The solid part of the FS is fed into the bio gas digester of $3 \mathrm{mtr}$ cube per day capacity. As a result of the anaerobic digestion Biogas will be formed.

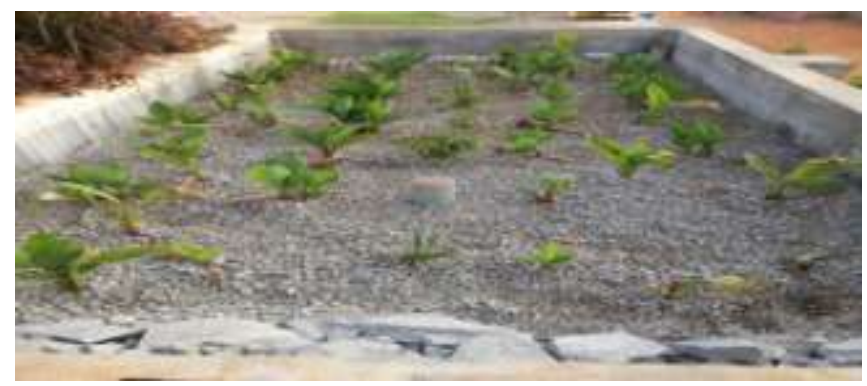

Fig 4: Planted gravel filter

\subsection{Integrated Settler with Anaerobic Baffle}

\section{Reactor}

An anaerobic baffled reactor consists of a tank with series of compartments with baffles to reduce the velocity of the flow. The baffles help for waste to interact with bacteria for more time which helps in more degradation organic matter.

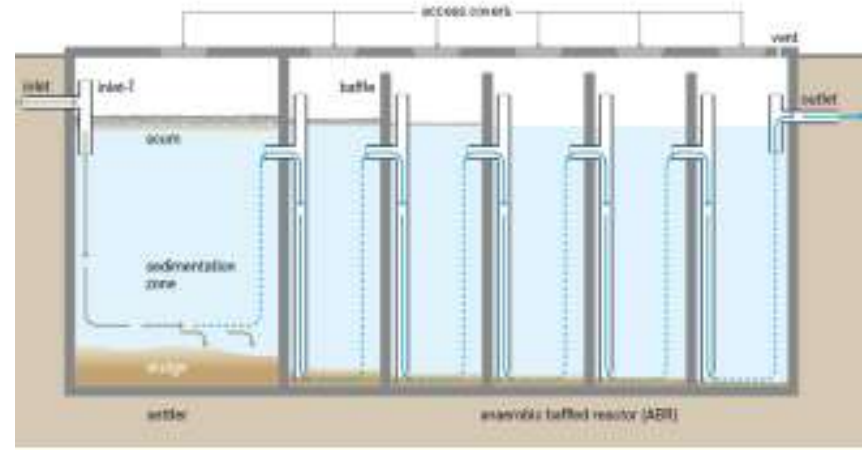

Fig 5: Typical cross section of ABR

\subsection{Stabilization Tank}

The solid part of the Faecal Sludge from the bio gas digester is being fed to the stabilization tank of 3 unequal compartments and $1.5 \mathrm{mtr}$ cube capacity per day. In this tank further digestion of FS happens.

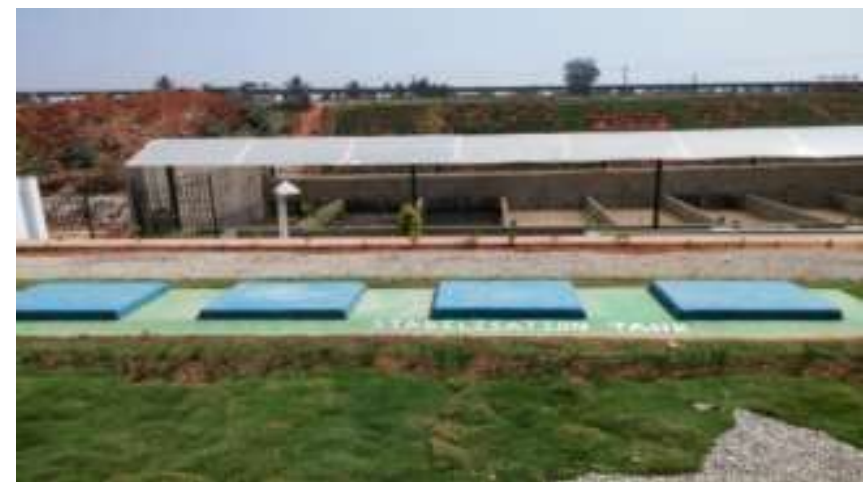

Fig 6: Stabilization Tank

\subsection{Planted Gravel Filter}

The liquid part of Faecal Sludge is being fed to the gravel filter, where removal of color and odor through aerobic process. The gravel filter consists of a layer of coarse aggregates below which a layer of fine aggregates is cast. The liquid part when fed to this filter passes through these gravel layers, which separates the remaining solid part and also some fine suspended particles and thus help removing the color and odor.

\subsection{Collection Tank}

Liquid part of Faecal Sludge is being collected in the collection tank from the gravel filter, where collection of treated waste water from PGF for agriculture and irrigation reuse.

\subsection{Drying Bed}

Sludge drying bed (SDB) is the most widely used method for sludge dewatering. Sludge drying involves natural ways of drying to mechanical ways of removing water content. SDB is generally used for small and medium sized communities. The selection of the technology will depend upon land availability, climatic factors, the quantity and composition of the sludge. The construction of this is usually undertaken with civil structure.

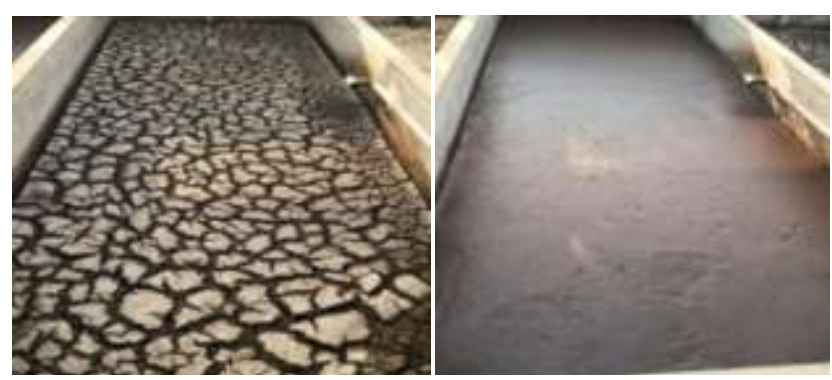

Fig 7: Drying bed at initial stage and final stage

\section{FAECAL SLUDGE TREATMENT UNIT DESIGN DETAILS}

Feeding Tank: The volume of the feeding tank is $3.6 \mathrm{~m} 3$, Sizes of Tank: $2.2 * 1.89 * 0.95 \mathrm{~m}$, Pore size of screen: $20 \mathrm{~m}$

Biogas digester: Volume of Biogas digester: $4.56 \mathrm{~m} 3$ including extension chamber

Stabilization Tank: Volume of the Stabilization tank: $9 \mathrm{~m} 3$ No of chambers:3

Anaerobic Baffle Reactor: Total volume of $A B R=10 \mathrm{~m}^{3} \mathrm{No}$ of chambers: 4, Stabilization tank-1no., anaerobic baffle reactor-4nos, Filters -2nos.

Planted Gravel Filter: Volume of PGF-3 m3,PGF Sizes$5.5 * 3 * 0.5$, Gravel height:200mm, Overall depth of PGF: $1 \mathrm{~m}$

Sludge Drying Bed: The total volume of SDB-25, No of Bed-10, Volume of each bed- $2.5 \mathrm{~m} 3 /$ day, the depth of filter materials- 0.8 


\section{METHODOLOGY}

A sample survey was conducted to find out types of crops, manure and willingness for use of fertilizer. A sample survey was conducted in the entire Devanahalli town for more than 30 days, collecting all the farmer's details like Name of the farmer, The types of crops grown by them, Amount spent by them on manure (per annum), Number of bags used by them to grow crops, The time in year of application of manure to their fields, Frequency of application of manure, Willingness to use the treated manure, How the sludge is disposed. The percentage organic waste produced in the entire town is calculated by collection of solid waste and by segregation of organic and inorganic portion. The total organic waste produced in the Devanahalli town is $32.76 \%$. The Waste Water sample at the Inlet of feeding tank and at the outlets of all other modules was collected and analyzed in the laboratory. The influent and effluent variations of $\mathrm{BOD}, \mathrm{COD}, \mathrm{pH}$, total solids and volatile solids were found and efficiency of each unit tabulated in Table 1.

\subsection{Co-Composting of Treated Facial Sludge with}

\section{Organic Fraction of Municipal Solid Waste}

Organic fraction of municipal solid waste is mixed with treated faecal sludge from faecal sludge treatment plant. The composting plant consisted of a composting platform equipped with a drainage system and covered by a roof. The mix is mixed, turned, watered and made compost heaps.

After composting period, compost was sieved and bagged in $50 \mathrm{~kg}$ bags.

\section{RESULTS}

The sample survey data collected shows that the willingness to use the treated sludge is very low. $74 \%$ of the farmers are reluctant to use the treated sludge as manure. $8 \%$ were ready to try and apply once and were ready to continue applying if the result was satisfactory. $18 \%$ were ready to apply the treated faecal sludge. (Fig: 8 and Fig: 9)

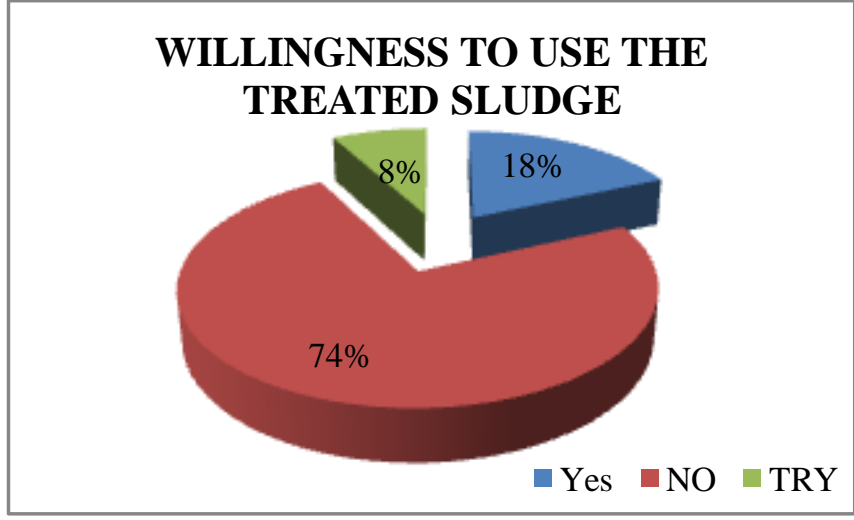

Fig 8: Willingness of farmers to use the treated sludge

\section{TYPES OF CROPS}

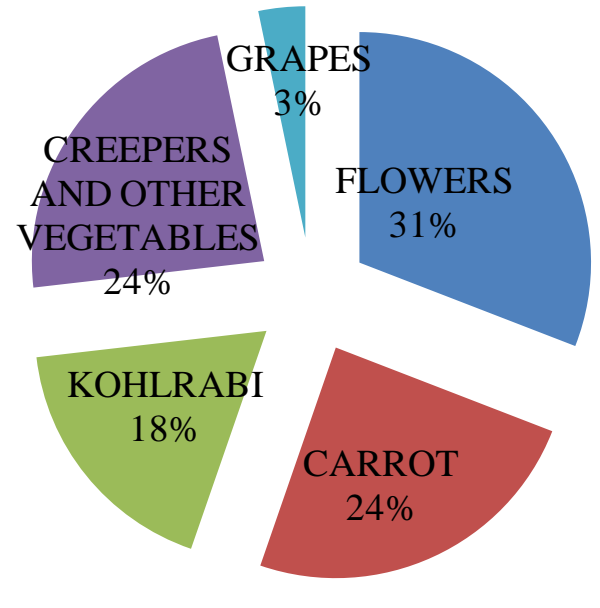

Fig 9: Percentage of crops grown in agricultural lands in Devanahalli

Table1: Efficiency of faecal sludge treatment plant units

\begin{tabular}{|l|l|l|l|l|l|l|l|}
\hline Data & Feeding tank & ABR & PGF & Collection tank & BGD & Sludge drying bed & efficiency \\
\hline BOD (mg/l) & 30000 & 500 & 100 & $<30$ & - & - & $99.9 \%$ \\
\hline COD (mg/l) & 60000 & 2000 & 150 & $<100$ & - & - & $99.83 \%$ \\
\hline pH & 7.2 & 7.5 & 7.7 & 7.9 & - & - & - \\
\hline Total solids (mg/l) & 50000 & - & - & - & 85000 & 2000 & $96 \%$ \\
\hline Volatile Solids (mg/l) & 40000 & - & - & - & 65000 & 480 & $98.8 \%$ \\
\hline
\end{tabular}




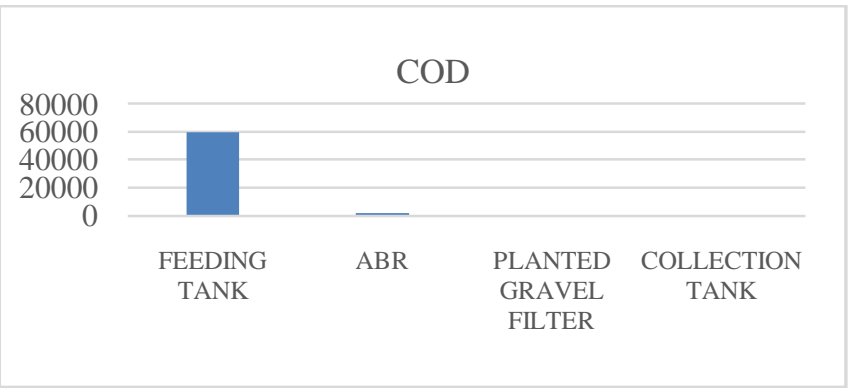

Fig 10: Variations of COD at Outlets of Various Modules.

The COD removal efficiency is found to be $99.83 \%$ and the major part of the COD is removed in the ABR. At the inlet of the ABR the COD was $60,000 \mathrm{mg} / \mathrm{l}$ and it was reduced to $2000 \mathrm{mg} / \mathrm{l}$ at the outlet of the ABR. The Planted gravel filter reduced the remaining $\mathrm{COD}$ and brought it down to $<100$ $\mathrm{mg} / \mathrm{l}$.

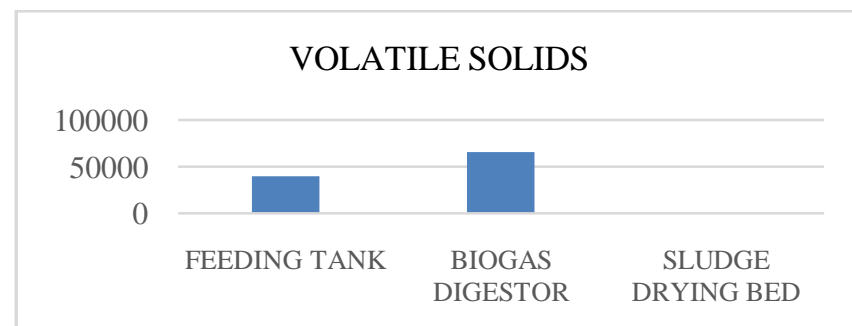

Fig 11: Variation of Volatile solids at Outlets of Various Modules

The Volatile solids removal efficiency is found to be $98.8 \%$. In the outlet feeding tank the volatile solids is $50,000 \mathrm{mg} / \mathrm{l}$. At the outlet of the Biogas digester it is found to be 65,000 $\mathrm{mg} / \mathrm{l}$. The Sludge drying bed is where the removal of the volatile solids takes place. It is reduced to $480 \mathrm{mg} / \mathrm{l}$.

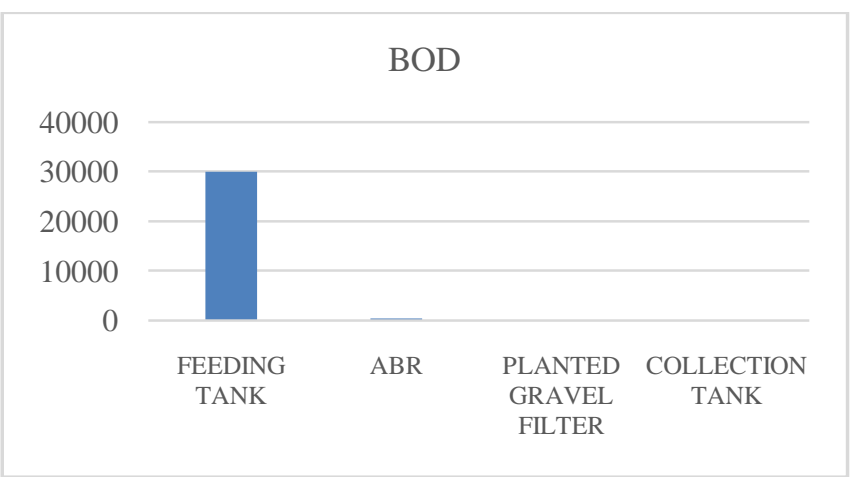

Fig 12: Variation of BOD at Outlets of Various Modules

The BOD removal efficiency is found to be $99.9 \%$. The treatment plant is found to be very efficient in removal of BOD. ABR plays a major role in the removal of BOD as shown in the graph above. The BOD at the inlet of the ABR was $30,000 \mathrm{mg} / \mathrm{l}$ whereas at the out of the ABR the BOD was $500 \mathrm{mg} / \mathrm{l}$. The remaining BOD is successfully reduced to a very negligible value of $<10 \mathrm{mg} / \mathrm{l}$ by the Planted gravel filter.

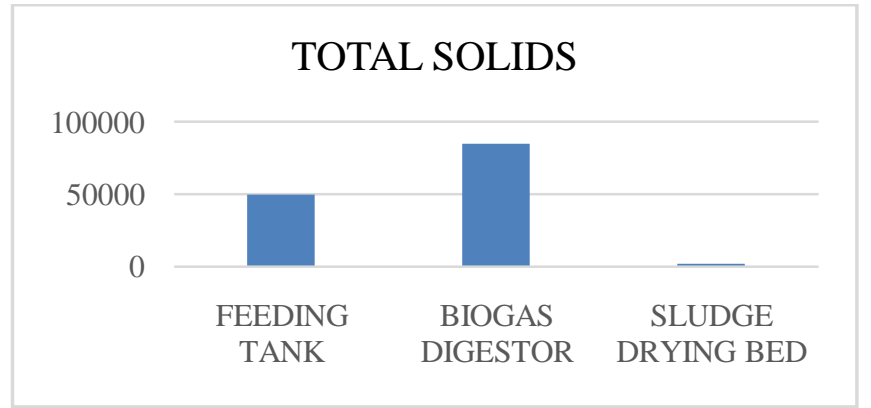

Fig 12: Variation of Total Solids at Outlets of Various Modules

The total solids present at the outlet of the feeding tank are $40,000 \mathrm{mg} / \mathrm{l}$. This increases in the biogas digester to 85,000 $\mathrm{mg} / \mathrm{l}$ due to the breaking down of the solids during the anaerobic digestion. The sludge drying bed reduces the amount of total solids to a very negligible value of 2000 $\mathrm{mg} / \mathrm{l}$. The efficiency of removal of the Total solids is found to be $96 \%$.

\subsection{Composition of Co-Compost}

Table 2 shows the composition of the compost during starting and ending period. Duration of composting is around 10 weeks.

Table 2: Composition of Co-compost

\begin{tabular}{|l|l|l|l|}
\hline \multirow{2}{*}{ Parameter } & \multirow{2}{*}{ Unit } & \multicolumn{2}{l}{ MW: FS (2:1) } \\
\cline { 3 - 4 } & & Start & End \\
\hline $\mathrm{pH}$ & & 7.8 & 7.9 \\
\hline Acidity & & 2.3 & 1.7 \\
\hline Moisture & $\%$ & 60.0 & 45 \\
\hline Carbon & $\%$ & 43 & 11 \\
\hline Nitrogen & $\%$ & 1.7 & 1.4 \\
\hline C:N & & 25.3 & 7.85 \\
\hline Potassium & $\%$ & 1.2 & 3.0 \\
\hline Calcium & $\%$ & 0.72 & 1.8 \\
\hline Magnesium & $\%$ & 1.2 & 0.6 \\
\hline Phosphorous & $\%$ & 0.9 & 3.5 \\
\hline E coli & $\begin{array}{l}\text { Colony } \\
\text { forming } \\
\text { units/g }\end{array}$ & $1.0 \times 10^{9}$ & 200 \\
& CFU/g & $6.0 \times 10^{7}$ & 212 \\
\hline $\begin{array}{l}\text { Total } \\
\text { Bacteria }\end{array}$ & & & \\
\hline Total Fungi & CFU/G & $1.0 \times 10^{6}$ & 160 \\
\hline
\end{tabular}

It can be observed from Tables that the microbial population is higher than the prescribed standards of $100 \mathrm{CFU} / \mathrm{gm}$. The compost can be used without any health effects.

\section{CONCLUSIONS}

The sample survey conducted at various parts shows that the nearby farmers are reluctant to use the treated faecal sludge as a soil conditioner.. Only $18 \%$ of the farmers were ready to use the treated sludge. About $8 \%$ were ready to try it once and $78 \%$ were reluctant to use the treated sludge. 
The amount of organic waste produced is found to be sufficient for the co composting process. Hence the co composting process is found to be feasible and useful to reduce solid waste of town.

The treated waste water from Faecal treatment plant had final BOD and COD values of $<30 \mathrm{mg} / \mathrm{l}$ and $<100 \mathrm{mg} / \mathrm{l}$ respectively. The final $\mathrm{pH}$ was found to be 7.9. All these values are below the prescribed standards. Hence the treated waste water is safe for irrigation purpose.

The Co composting of the faecal sludge proved to be very effective in removal of the harmful pathogen content in the faecal sludge. The composition of compost consists of $\mathrm{pH}-$ 7.8, moisture - 45\%, C:N - 7.85, Potassium -3\%, Calcium$1.8 \%$, Magnesium $-0.6 \%$, Phophorus-3.5\%, E.Coli-200 $\mathrm{CFU} / \mathrm{gm}$, total bacteria-212 CFU/gm. Hence making the treated faecal sludge safe to be used as soil conditioner.

The study will have a positive impact on the environment and health as it will eradicate the practice of unscientific and unhygienic open dumping method of disposal.

\section{ACKNOWLEDGEMENT}

The authors express their sincere thanks to Principal and Management of Dayananda Sagar college of Engineering, for their encouragement and support Bangalore, Karnataka.

\section{REFERENCES}

[1]. Cofie, O., Strauss, M., Montangero, A., Zurbrugg, C. and Drescher, S. (2003),Co-composting of faecal sludge and municipal organic waste for urban and periurban agriculture in Kumasi, Ghana

[2]. Hoornweg, D., Thormas, L., and Otten, L. (1999). Composting and its applicability in developing countries.

[3]. Impraim, R. (2013), "The processes involved in the fortifer production in the pilot project in Accra".

[4]. Keraita, B., Jiménez, B. and Drechsel, P. (2008) 'Extent and implications of agricultural reuse of untreated, partly treated and diluted wastewater in developing countries' Agriculture.

\section{BIOGRAPHIES}

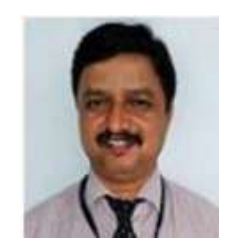

\section{B. T. Shivendra,}

Working as a Associate professor in

Department of Civil Engineering, DSCE Bangalore, He has a experience of twenty two years in teaching. He has published more than twenty five papers in International and National conference and seminar.

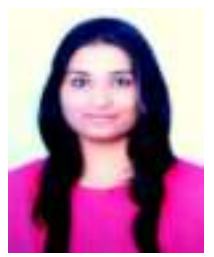

Tejaswini M, BE MTech

Working as a Assistant professor

Department of Civil Engineering, DSCE

Bangalore, She had more than three years work experience in teaching. She had published paper in National conference

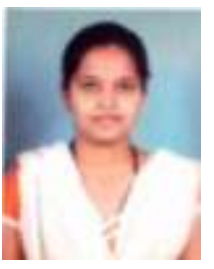

Poornima Kamatagi, BE MTech

Working as a Assistant professor Department of Civil Engineering, DSCE Bangalore, She had more than three years work experience in teaching. She had published paper in National conference

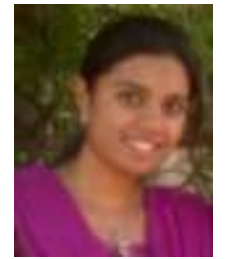

\section{Tejaswini P S, BE ME}

Working as a Assistant professor Department of Civil Engineering, DSCE Bangalore, She had more than five years work experience in teaching and published papers in National conference. 